\title{
Agribusiness participation in the economic structure of a Brazilian region: analysis of GDP and indirect taxes
}

\author{
Participação do agronegócio na estrutura econômica de uma região \\ brasileira: análise do PIB e dos impostos indiretos \\ Ricardo Kureski ${ }^{1}$ (D), Vilmar Rodrigues Moreira ${ }^{1}$ (), Claudimar Pereira da Veiga ${ }^{2}$ (1) \\ 1Pontifícia Universidade Católica do Paraná (PUCPR), Curitiba (PR), Brasil. E-mails: ricardo.kureski@pucpr.br; \\ vilmar.moreira@pucpr.br \\ ${ }^{2}$ Universidade Federal do Paraná (UFPR), Curitiba (PR), Brasil. E-mail: claudimar.veiga@gmail.com
}

\begin{abstract}
How to cite: Kureski, R., Moreira, V. R., \& Veiga, C. P (2020). Agribusiness participation in the economic structure of a Brazilian region: analysis of GDP and indirect taxes. Revista de Economia e Sociologia Rural, 58(3), e207669. https://doi.org/10.1590/1806-9479.2020.207669
\end{abstract}

\begin{abstract}
Agribusiness, including all its dimensions, is the largest economic sector in Brazil and plays a fundamental role in the development of the country's economy. About one-fourth of the Brazilian Gross Domestic Product (GDP) is composed of agribusiness. The objective of this article is to evaluate the participation of agribusiness in the economy of an important region of Brazil from 2010 to 2015. The evaluation was carried out through the decomposition of GDP, with an analysis of aggregate inputs, agro-livestock products, industrialization, and services. This article presents three main contributions to the understanding and composition of agribusiness GDP. The novelty of this article lies in the fact that it is the first work in the literature to present the steps of the methodology for calculating GDP in a region representing Brazilian agribusiness, considering its aggregates and relating the generation of taxes and other factors. In addition to the empirical and methodological contributions, this article highlights the relevance of agribusiness to the Brazilian economy, which, in turn, has relevance to global agribusiness.
\end{abstract}

Keywords: agribusiness economics, brazilian economy, gross domestic product, economic assessment, agro-livestock economics.

Resumo: O agronegócio, incluindo todas as suas dimensões, é o maior setor econômico do Brasil e desempenha um papel fundamental no desenvolvimento da economia do país. Neste contexto, um quarto do produto interno bruto (PIB) brasileiro é composto do agronegócio. O objetivo deste artigo é avaliar a participação do agronegócio na economia de uma importante região do Brasil de 2010 a 2015. A avaliação foi realizada por meio da decomposição do PIB, com uma análise de insumos agregados, produtos agropecuários, industrialização e serviços. Este artigo apresenta três principais contribuições para o entendimento e a composição do PIB do agronegócio. A novidade deste artigo reside no fato de ser o primeiro trabalho da literatura a apresentar as etapas da metodologia de cálculo do PIB em uma região representativa do agronegócio brasileiro, considerando seus agregados e relacionando a geração de impostos e outros fatores. Além das contribuições empíricas e metodológicas, este artigo destaca a relevância do agronegócio para a economia brasileira, que, por sua vez, tem relevância para o agronegócio global.

Palavras-chave: economia do agronegócio, economia brasileira, produto interno bruto, avaliação econômica, economia agropecuária.

\section{Introduction}

Agribusiness has always played a key role in the development of the Brazilian economy. Brazil's economic outbreaks during coffee, cattle, sugarcane, rubber, cocoa, and other "cycles" show the sector's economic and social contributions (Wilkinson et al., 2017; Córdoba et al., 
2018). The country's economic tradition in agribusiness is a trend that will prevail in the future, mainly due to the availability of its vast natural resources (Sehnem \& Oliveira, 2017). Of Brazil's 880 million hectares, 388 million are arable and 90 million have not yet been exploited (Portal do Agronegócio, 2014). This availability of area, which does not exist in most countries, coupled with global growth in food demand, creates a positive scenario for national agribusiness. It is a vitally important economic sector of Brazil since it generates a significant portion of employment, positively supports the trade balance with the strength and magnitude of its exports, and substantially influences the composition of the Brazilian GDP (U.S. Department of Agriculture, 2016; Machado Filho et al., 2017; Cunha et al., 2018).

Brazilian agribusiness is the largest economic sector in the country if grouped in all its dimensions: production, consumption, industry, and services. About one-fourth of the Brazilian Gross Domestic Product (GDP) is composed of agribusiness (Moreira et al., 2016). The sector employs 38\% of the country's labor force and accounts for about $40 \%$ of the volume of domestic exports (Martins et al, 2014; loris, 2016), producing the largest trade balance among all economic sectors in Brazil.

Brazil has reached a leading position in international exports in several agricultural commodities (Brasil, 2016). In 2015, Brazil was the world's largest exporter of sugar, coffee, orange juice, beef, chicken, and tobacco. It is the world's second-largest exporter of cellulose, soy and its derivatives, and the third-largest exporter of corn and pork. The country changed from being a large food importer until the 1970s to currently assuming the world's largest agricultural trade balance (Brasil, 2016; Companhia Nacional de Abastecimento, 2014).

Based on the literature, it is verifiable that agribusiness plays a fundamental and strategic role in Brazil (Freitas Filho et al., 2002; Brenes et al., 2014; Moreira et al., 2016). In 2015, the sector exported US\$ 88.2 billion, or 43\% of the country's foreign sales. The 2014-15 grain harvest resulted in 207.7 million tons (Companhia Nacional de Abastecimento, 2014), a 70\% increase from ten years ago. Brazil is one of the major players in the export of agro-livestock production, having opened the market in strategic countries for international trade.

Brazil's Paraná state, the region that is the subject of this study, is one of the units of the federation that stands out among the largest producers of agribusiness, exporting products to countries on all continents, especially, with greater volume, to the European Union and China (Brasil, 2016). Although the state contributed only 6.3\% to the national GDP in 2015, it represents the country's fifth-largest economy and leads the production of various agribusiness items. Table 1 shows the production of the main crops (2014-15 harvest season) and the participation of Paraná state in the national ranking.

Table 1 - Paraná: production, ranking, and national participation of major crops - 2014-15 harvest season.

\begin{tabular}{ccccc} 
Product & Unit & Total Paraná & $\begin{array}{c}\text { National PR } \\
\text { ranking }\end{array}$ & PR / BR \\
Wheat & Million t & 3.47 & $1^{\text {st }}$ & $60.0 \%$ \\
Bean & Thousand t & 666.4 & $1^{\text {st }}$ & $30.0 \%$ \\
Barley & Thousand t & 165.4 & $1^{\text {st }}$ & $52.0 \%$ \\
Soy & Million t & 16.7 & $2^{\text {nd }}$ & $17.8 \%$ \\
Corn & Million t & 15.54 & $2^{\text {nd }}$ & $20.0 \%$ \\
Oats & Thousand t & 123.3 & $2^{\text {nd }}$ & $18.0 \%$ \\
Manioc & Million t & 3.71 & $2^{\text {nd }}$ & $19.0 \%$ \\
Sugar cane & Million t & 41.28 & $5^{\text {th }}$ & $6.0 \%$ \\
Total Ethanol & Billion I & 1.6 & $5^{\text {th }}$ & $5.0 \%$ \\
Sugar & Million t & 2.7 & $3^{\text {rd }}$ & $8.0 \%$ \\
Orange & Thousand t & 900.8 & $4^{\text {th }}$ & $6.0 \%$ \\
Arabica coffee & Million bags (60 kg) & 1.11 & $6^{\text {th }}$ & $2.7 \%$ \\
\hline
\end{tabular}

Source: Companhia Nacional de Abastecimento (2014). 
The study presented in this article brings important contributions to the understanding and composition of agribusiness GDP in an important region of Brazil: Paraná state. The first original contribution of this work is to examine an issue that has been little evaluated in the literature, with emphasis on investigating the participation of agribusiness in the economy of Paraná state and real growth rate of agribusiness GDP, through the analysis of GDP composition, evaluating aggregate inputs, agro-livestock products, industrialization, and services. The main contribution is the estimates of the real growth rate of agribusiness GDP and the composition of the indirect tax burden in the agribusiness of Paraná. This can yield better practical results for public policy decision-makers.

The second contribution presents the evolution of agribusiness between the years 2010 and 2015, its relative importance in mitigating the effects of the economic crisis of 2015, and the contribution of agribusiness in the collection of indirect taxes. Finally, the third contribution is being the first empirical article to present the steps of the methodology for calculating the GDP, considering also the real GDP growth rate of agribusiness, according to the aggregates and its relation to the effects of the economic crisis and tax collection. In addition to empirical methodological contributions, the article highlights the importance of agribusiness in the Brazilian economy, which in turn has relevance in world agribusiness.

\section{Material and Methods}

To estimate the GDP of agribusiness, a specific methodology is used that brings together all the activities that form this economic segment. In this work, the methods developed by Bonelli et al. (2011), Barros et al. (2015), Finamore \& Montoya (2003), and Kureski et al. (2015) were used, adapted to the data availability of Paranás economy. In the case of research by Kureski et al. (2015), which measured the GDP of the agribusiness of Paraná from 2006 to 2011, the progress of this research is in the determination of real GDP growth in agribusiness and the composition of the indirect tax burden in the agribusiness of Paraná.

The methodologies use national or regional input-output matrix tables. However, since Paraná state does not have a regional input-output matrix, the solution was to use the methodology of Bonelli et al. (2011), who estimate the agribusiness GDP of the state of Espírito Santo from the input-output matrix of Brazil and the data of the regional accounts. However, at the time of writing this article, the Brazilian Institute of Geography and Statistics (IBGE) had published the Resource and Usage Table only from 2010 to 2013. The methodological procedure presented by Guilhoto \& Sesso Filho (2005) was adopted to elaborate the input-output matrix, which consists of transforming the resource table and uses consumer prices to basic prices. Thus, values related to transportation margins, trade margins, Brazilian taxes (IPI, ISS, ICMS, and other) on imports are deducted from the table of resources and uses. For more details, see Guilhoto \& Sesso Filho (2005).

\subsection{Input-Output Model}

This article uses the input-output model that allows for the calculation of the GDP of Paraná's agribusiness and its contribution to the collection of indirect taxes. The input-output matrix presents the monetary values of purchases and sales transactions among economic activities. It shows the demand for inputs (raw material) that are used on the production of intermediate and final goods and services in a given country or region. Thus, it is possible, for example, to determine how much agro-livestock activity has bought and sold in inputs and final products, allowing the estimation of the backward and forward linkage as well as the GDP of this production chain. Table 2 presents the input-output system in which the production (V) and use (Un) matrices are considered, according to the methodology adopted by the Brazilian Institute of Geography and Statistics (IBGE). 
Table 2 - Calculation of technical coefficient matrices

\begin{tabular}{ccccc} 
& $\begin{array}{c}\text { National } \\
\text { products }\end{array}$ & Activities & Final demand & $\begin{array}{c}\text { Production } \\
\text { value }\end{array}$ \\
National products & & Un & Fn & $\mathrm{q}$ \\
Imported products & $\mathrm{Um}$ & $\mathrm{Fm}$ & $\mathrm{g}$ \\
Activities & $\mathrm{V}$ & $\mathrm{Tp}$ & $\mathrm{Te}$ & \\
Taxes & & $\mathrm{y}^{\prime}$ & \\
Added value & $\mathrm{g}$ & $\mathrm{g}^{\prime}$ & \\
Output value & $\mathrm{q}^{\prime}$ & $\mathrm{T}$ & & \\
\hline
\end{tabular}

Source: Feijó \& Ramos (2018), Instituto Brasileiro de Geografia e Estatística (2007). Legend: V = Output matrix. It presents the output value of each of the products for each activity; $q=$ Vector with the gross value of the total output per product; Un = Matrix of national intermediate consumption. It presents the value of the consumed products of domestic origin for each activity; Um = Matrix of imported intermediate consumption. It presents the value of the consumed products of external origin for each activity; $\mathrm{Fn}=$ Matrix of the final demand for domestic products. It shows the value of domestic products consumed by the categories of final demand (final consumption of public administrations, final consumption of non-profit institutions serving households, final consumption of households, exports, gross fixed capital formation, and inventory change); $\mathrm{Fm}=$ Matrix of the final demand for imported products. It presents the value of the products of external origin consumed by the final demand categories; $E$ = Matrix of the final demand for the activity. It represents the portion of the output value of an activity destined to the final demand. These data are not observed; they are calculated from $\mathrm{Fn} ; \mathrm{Tp}=$ Matrix of the values of taxes and subsidies associated with products levied on goods and services absorbed (inputs) by the productive activities; $\mathrm{Te}=$ Matrix of the values of taxes and subsidies linked to products levied on goods and services absorbed by final demand.

In the matrix of resources and uses adopted by the IBGE, the lines represent the products and the columns represent the activities. For the estimation of the input-output matrix through the products and activities, some assumptions are necessary. For the model, it is hypothesized that this is a linear and homogeneous function; that is, each commodity is supplied by a single activity with constant scale yield. Another hypothesis relates to the additivity, in which the total effect of output is the sum of the separate effects.

In obtaining the direct and indirect effects, it is necessary to group the relations between activities and products into relations between activities (row) and activities (column). To this end, the hypotheses of market-share (matrix D) are adopted, in which each activity will meet this demand in proportion to their participation in the production of the product and the industry technology (matrix B), where technology for the production of the product is that of the activity that produces it.

For the calculation of the technical coefficients, matrix $B$ and $D$ must first be obtained. The matrix B, based on the "industry technology" hypothesis, demonstrates the share of intermediate consumption in the output value. It is formalized through Equation 1.

$B=U n * D I A G(g)^{-1}$

Where: Un = Matrix of intermediate consumption values of national products; $g$ = Vector production by activity.

The $\mathrm{D}$ matrix, based on the assumption of market-share, in which the share of each activity in the production is constant, is obtained from Equation 2.

$D=V^{\prime} * D I A G(q)^{-1}$

Where: $V=$ Matrix that contains the output values of the products according to the activity of origin; $q=$ Vector of the output values of the products.

By multiplying matrix $D$ by matrix $B$, we obtain the matrix of the inter-sectorial technical coefficients $(D * B)$. This matrix is used to obtain the Leontief matrix and the vector of production values (g), activity by activity, through Equation 3. 
Where: $g=$ Vector of output values by activity; $D * B=$ Matrix of inter-sectorial technical coefficients; $(I-D * B)^{-1}=$ Matrix of the most indirect direct technical coefficients; $D$ * $F_{i}=$ Total demand for the activity.

\subsection{Gross Domestic Product of Agribusiness}

The methodology used to estimate GDP and taxes is based on the work of Finamore \& Montoya (2003). To calculate the -added value resulting from sales to agribusiness, it is necessary to calculate the coefficient of the added value. This is necessary to avoid the multiple counting error since the value supplied does not correspond to the -added value, but to a part of the value of the production that is supplied to the activity by other sectors. The coefficient of the added value is calculated through Equation 4.

$V A C_{i}=V A_{p m i} / X_{i}$

Where: $V A C_{i}=$ value added coefficient; $V A_{p m i}=$ Value added at market price; $X_{i}=$ Output value.

By multiplying the coefficient of the value added by the value of the supply of inputs, the GDP of the supply of inputs to agribusiness is obtained by using Equation 5.

$G D P I=\left(\sum_{i=j}^{n} Z_{i}\right) * V A C_{i}$

Where: $\mathrm{GDP}_{1}=$ aggregate I GDP (inputs) of agribusiness; $\mathrm{Z}_{\mathrm{i}}=$ total input value of sector $\mathrm{i}$ for agribusiness; $\mathrm{VAC}_{i}=$ value added coefficient of sector $\mathrm{i}$.

The supply of inputs to the sector itself was not calculated by Equation 5 . Thus, the share of GDP of input sales within the activity itself is incorporated into the agro-livestock GDP value.

For agriculture activities (including support for agriculture and post-harvest), livestock (including support for livestock and forestry), and fishing and aquaculture, the output value was multiplied by the added value index. Thus, the GDP of aggregate II (agro-livestock product) is given by Equation 6 .

$G D P_{I I}=V B P * V A C_{i}$

Where: $\mathrm{GDP}_{\|}=$aggregate II GDP of agribusiness; VBP = Value of production at the basic price of agriculture; $\mathrm{VAC}_{i}=$ value added coefficient of sector $\mathrm{i}$.

In the next step, the GDP of the agro-industrial sector is estimated: industries that supply inputs, such as the defense segment; industries that transform agro-livestock products into final products to be sold to consumers; and the footwear and leather goods manufacturing segment. The estimation begins with the determination of the added value for each agro-industrial segment. Then the added value that corresponds to the supply of input to aggregate II is subtracted. The GDP result of aggregate III (agroindustry) is obtained through Equation 7.

$G D P_{I I I}=\sum_{i=1}^{n}\left(V A_{p m i}-Z_{i}^{*} V A C_{p m i}\right)$

Where: $\mathrm{GDP}_{\text {III }}=$ aggregate III GDP of agribusiness; VA $\mathrm{pmi}_{\text {i }}=$ Value added at a market price of the agribusiness sector $\mathrm{i} ; \mathrm{Z}_{\mathrm{i}}=$ Total value of the $\mathrm{i}$ sector input; $\mathrm{VAC}_{\mathrm{pmi}}=$ value added coefficient at the market price of the i sector. 
The GDP of aggregate IV refers to services related to agribusiness. For its calculation, it is necessary to first find the final domestic demand, which considers the global demand subtracted from the net taxes and values of imported products. The final domestic demand is calculated by Equation 8 .

$D F D=T F D-N I T F D-P I F D$

Where: DFD = Domestic final demand; TFD = Total final demand; IILDF $=$ Net indirect taxes paid by final demand; PIDF = Products imported by final demand.

Thus, the GDP of the aggregate IV (services) is obtained by Equation 9.

$$
G D P_{I V}=\left(V A C_{p m}+\text { VATrans }_{p m}+V A S_{p m}-Z^{*} C V A_{p m}\right) \cdot\left(\Sigma \frac{F D_{i}}{D F D}\right)
$$

Where: $V A_{p m}=$ value added coefficient at market price; VATrans $_{\mathrm{pm}}=$ value added of transportation at market price; $\mathrm{VAS}_{\mathrm{pm}}=$ value added services at market price; $\mathrm{Z}=$ total value of the input; $F D_{i}=$ final demand of agribusiness activities; $\mathrm{DFD}=$ domestic final demand.

Agribusiness GDP corresponds to the sum of the GDPs of the aggregates, according to Equation 10.

$G D P_{\text {Agribusiness }}=G D P_{I}+G D P_{I I}+G D P_{I I I}+G D P_{I V}$

The agribusiness GDP was measured at basic prices, excluding taxes to determine the tax burden related to indirect taxes. The procedure is the same as above, but to calculate the coefficient of value added, it uses the value added at the basic price. The difference between agribusiness GDP at market price and GDP at basic price corresponds to the tax burden of indirect taxes.

\section{Agro-Livestock GPD of Paraná And Indirect Taxes}

Paraná state, located in the Southern Region of Brazil, represented $6.3 \%$ of the Brazilian economy in 2013, according to the Brazilian Institute of Geography and Statistics (IBGE, 2015). Agro-livestock represented $9.48 \%$ of the state's GDP, surpassing the share of agro-livestock in the national economy, which represented $5.3 \%$. In agriculture, the production of soybeans stands out, as Paraná is the second largest national producer in 2014 with 14.913 million tons produced, corresponding to $17.19 \%$ of Brazilian production. Other products that stand out are corn and wheat, with $19.81 \%$ and $60.94 \%$ of national production, respectively. In the same way, the meat segment has experienced significant growth in recent years. Paraná is the largest producer and exporter of poultry in the country with $29.79 \%$ of exports in 2014, corresponding to 2.363 billion dollars (Sindicato das Indústrias de Produtos Avícolas do Estado do Paraná, 2016). Equally important is the pork production and slaughtering segment, in which Paraná is the second largest national producer, exporting mainly to China and Europe.

Figure 1 shows the evolution of the share of agribusiness in the state economy from 2010 to 2015. Table 3 describes the results of the GDP of Paraná and the GDP of agribusiness and their annual change in volume at prices in the period analyzed by this study. The relative importance of agribusiness in GDP increased from $28.75 \%$ in 2010 to $30.74 \%$ in 2015, totaling 112,245 million reais. It can be seen that in 2011 , there was an increase in the share of GDP, but a decrease of $-1.0 \%$ in the real growth of agribusiness GDP. In this sense, it should be noted that the gain in participation was positively influenced by the increase in the price of soybeans, which increased by 27.4\% (from US\$ 386 to US\$ 492 per ton) in 2011 (Portal Brasil, 2012). 


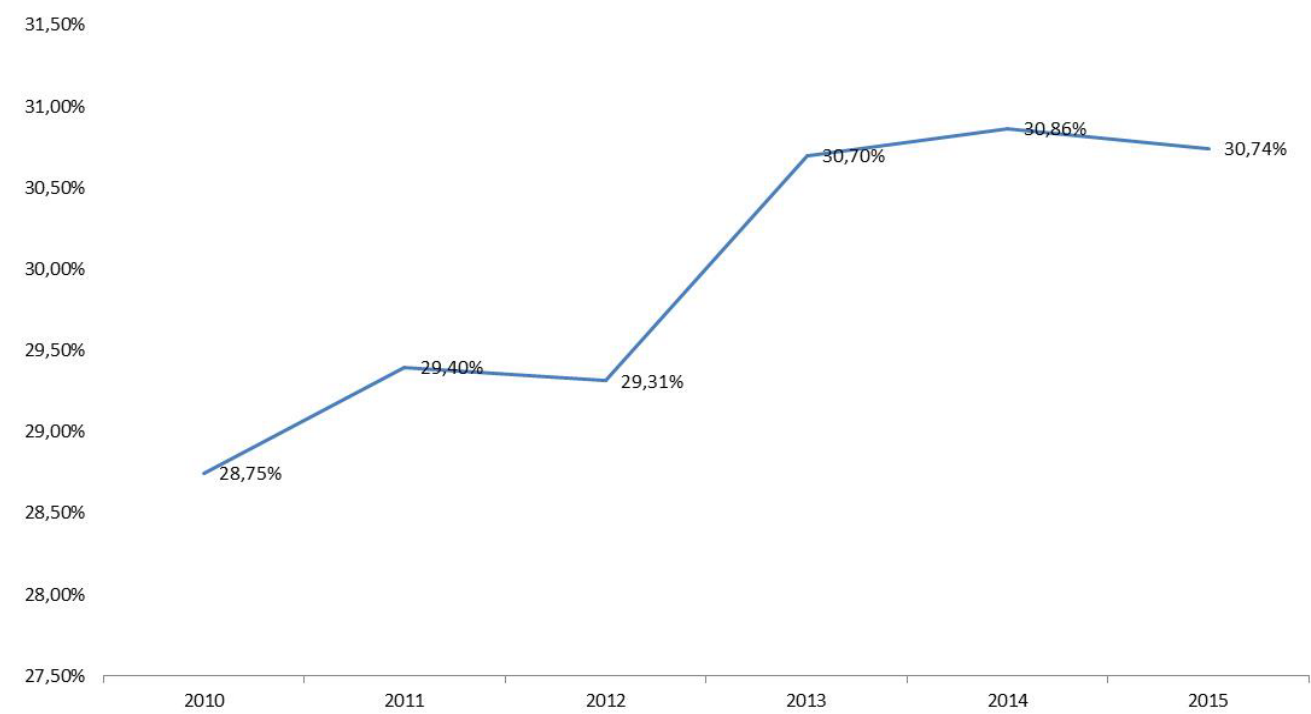

Figure 1 - Participation of agribusiness in the economy of Paraná - 2010-2015. Source: Research Data

Table 3 - Paraná GDP and Agribusiness: 2010-2015

\begin{tabular}{|c|c|c|c|c|c|c|c|}
\hline \multirow{3}{*}{ YEAR } & \multicolumn{3}{|c|}{ Gross Domestic Product } & \multicolumn{3}{|c|}{$\begin{array}{c}\text { Gross Domestic Product of } \\
\text { Agribusiness }\end{array}$} & \multirow{3}{*}{$\begin{array}{c}\text { Agribusiness } \\
\text { participation } \\
\text { in GDP (\%) }\end{array}$} \\
\hline & \multicolumn{2}{|c|}{1000000 R \$ } & \multirow[b]{2}{*}{$\begin{array}{l}\text { Variation } \\
\text { In } \\
\text { volume } \\
(\%)\end{array}$} & \multicolumn{2}{|c|}{1000000 R \$ } & \multirow[b]{2}{*}{$\begin{array}{c}\text { Variation } \\
\text { In volume } \\
(\%)\end{array}$} & \\
\hline & $\begin{array}{c}\text { Current } \\
\text { prices }\end{array}$ & $\begin{array}{l}\text { Prices of } \\
\text { the } \\
\text { previous } \\
\text { year }\end{array}$ & & $\begin{array}{c}\text { Current } \\
\text { prices }\end{array}$ & $\begin{array}{l}\text { Prices of } \\
\text { the } \\
\text { previous } \\
\text { year }\end{array}$ & & \\
\hline 2010 & 225211 & - & - & 64737 & & - & 28.75 \\
\hline 2012 & 257122 & 235564 & 4.6 & 75585 & 64121 & (-) 1.0 & 29.40 \\
\hline 2012 & 285620 & 257012 & (-) 0.0 & 83726 & 74295 & (-) 1.7 & 29.31 \\
\hline 2013 & 333481 & 301185 & 5.4 & 102377 & 91915 & 9.8 & 30.70 \\
\hline 2014 & 348084 & 328531 & (-) 1.5 & 107433 & 100652 & (-) 1.7 & 30.86 \\
\hline 2015 & 365 & 338338 & $(-) 2.8$ & 112245 & 106986 & (-) 0.4 & 30.74 \\
\hline
\end{tabular}

Source: GDP of Brazil and Paraná - IBGE and IPARDES. Notes: Agribusiness GDP calculated by the authors. Agribusiness GDP for 2015 is estimated, subject to change.

The slight decline in agribusiness participation in 2012 can be attributed to the decrease in soybean production, affected by the drought, and the poor performance of the food manufacturing industry segment. In 2013, agribusiness showed participation of $30.70 \%$ in the GDP of Paraná and an increase of $9.8 \%$, mainly due to the performance of soybean production, poultry farming, and food manufacturing industry. Castro (2013), when analyzing the performance of Paraná agriculture, said: "Paraná should harvest 36.37 million tons of grains, representing an increase of $17.7 \%$ over the previous year, with the most significant variations identified in soybeans (46\%) and maize $(5.9 \%)$ farming, between the harvests of 2012 and 2013". Regarding 2014, despite the 1.7\% decrease in agribusiness activity, the sector increased the share in the economy to $30.86 \%$. According to Castro (2015), there was a strong increase in the value of meat exports (9.7\%)in that year, which probably influenced this result.

In 2015 , the state economy shrank by $2.8 \%$, yet agro-livestock activity had a positive influence, with the expansion of wheat production and especially livestock production. In 2015, 1.481 million tons were exported, a volume of $15.17 \%$ higher than in 2014 , and accounting for $34 \%$ of Brazilian shipments (Gazeta do Povo, 2016).

In the state economy in 2015 , there was a variation of $-2.8 \%$ in GDP. This recession first hit industrial activity as a whole, exhibiting a variation of $-9.2 \%$, according to the Monthly 
Industrial Survey - Physical Production of IBGE (PIM-PF). The result of the economy of Paraná was not aggravated due to the performance of activities related to agribusiness, which fell by $-0.4 \%$, presenting a $30.74 \%$ share in the economic activity of Paraná. Among the main agribusiness products, the increase in soybean and sugarcane production, stood out, which rose $15.0 \%$ and $6.9 \%$, respectively.

The structure of agribusiness can be analyzed by the four segments that comprise it: Aggregates Inputs, Agro-livestock Products, Agroindustry, and Services. Figure 2 shows the evolution of the share of each segment in the agribusiness GDP.

In 2010, the agribusiness GDP was 64.737 billion reais. The share of agro-livestock inputs represented $5.13 \%$, of agro-livestock $28.72 \%$, of agroindustry $30.50 \%$, and services $35.65 \%$. By contrasting the years 2010 and 2015, it is possible to verify a change in the composition of agribusiness GDP. The agro-livestock product is among the segments that contributed the most to the important change, with an increase of 3.64\%, followed by services, with an increase of $2.87 \%$. In the period studied, according to statistics from the Ministry of Development, Industry and Foreign Trade (MDIC), the shares of exports of the soybean and meat complex in Paraná state increased from $27.21 \%$ and $13.51 \%$ in 2010 to $31.9 \%$ and $17.5 \%$ in 2015, respectively. This dynamism positively influenced trade and transport activities, changing the composition of agribusiness GDP in 2015.

In the context analyzed, the relevance and representativeness of agribusiness for the economy of Paraná in 2015 are noteworthy. The GDP of agro-livestock inputs was $\mathrm{R} \$ 5,009$ billion of which the agro-livestock product corresponded to 36.317 billion, agroindustry to 27.685 billion, and services to 43.233 billion. Considering that the state's GDP in 2015 was R $\$ 112.245$ billion, agribusiness corresponded to $30.74 \%$ of Paraná's economy.

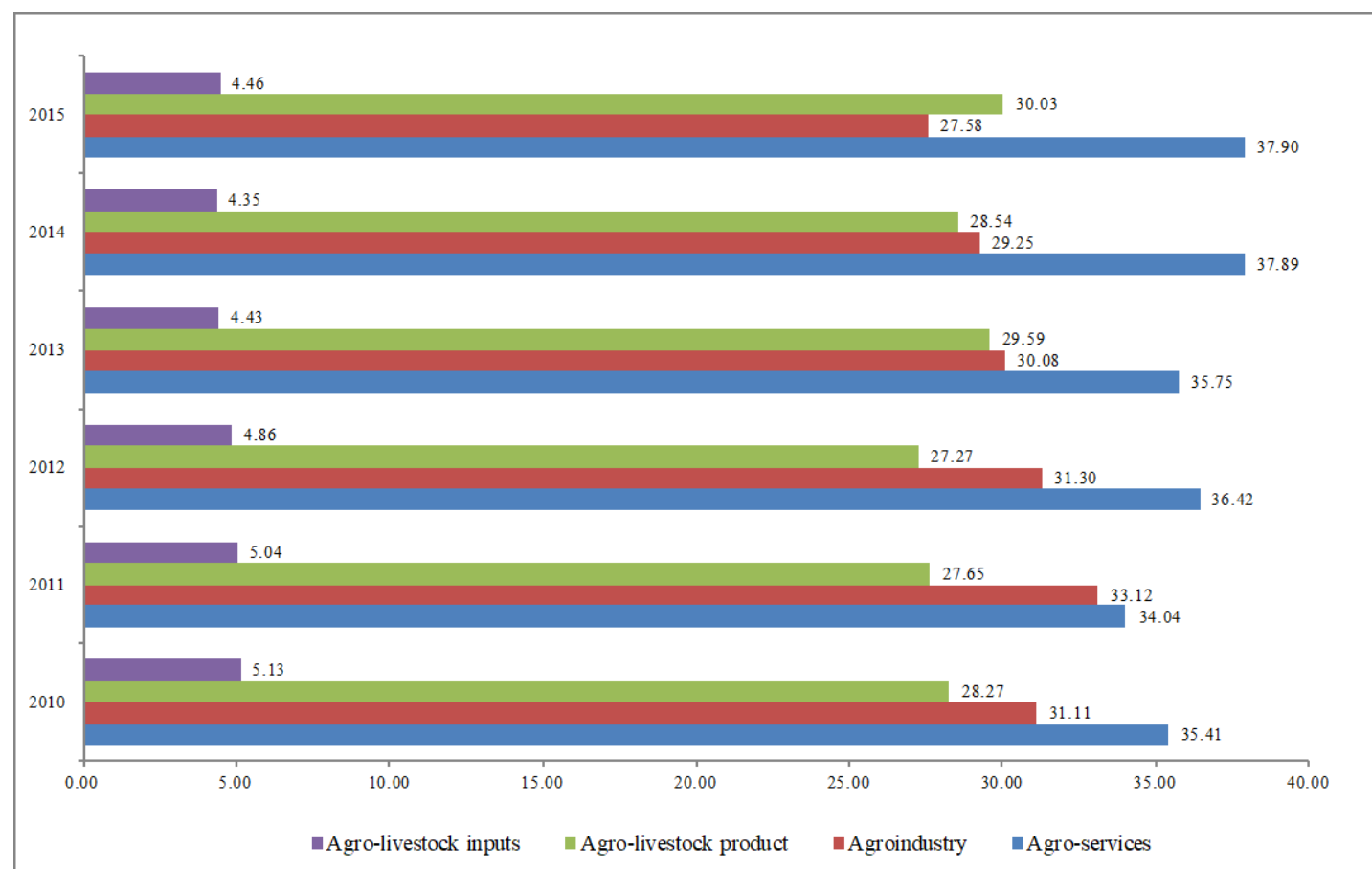

Figure 2 - Share of the segments in the GDP of the agribusiness of Paraná - 2010-2015

Regarding the growth rate of agribusiness, we can see a better performance of the agro-livestock product segment, which increased by $17.84 \%$ in 2013, as shown in Table 4. The accumulated rate in the period reached $13.28 \%$, higher than the total of the economy of Paraná (5.5\%). Essentially, this result was influenced by the dynamism in soy production, livestock production, and cereal production. In the agroindustry segment, there was a decline of $-3.71 \%$ in 2014 and $-4.26 \%$ in 2015, which is still lower than the decline rates in Paraná's GDP. These results are due to the decline in furniture manufacturing (-7.4\%), and 
especially in Paraná's important industrial segment, the manufacturing of food products, which showed a reduction of $-5.65 \%$ in 2014 , according to the Monthly Survey of Industry of IBGE, 2015. There were also identified decreases in the services segment, mainly due to the retraction of agroindustry production, as the fall in production reduced the quantity of products traded and transported, which consequently affect the result of this segment.

Table 4 - Real GDP growth rate of Paraná agribusiness: 2011-2015

\begin{tabular}{cccccc} 
Segment & \multicolumn{7}{c}{ Real Growth (\%) } \\
Agro-livestock inputs & 2011 & 2012 & 2013 & 2014 & 2015 \\
Agro-livestock product & 0.13 & -4.64 & 8.29 & 2.85 & 3.02 \\
Agribusiness & -3.78 & -9.37 & 17.84 & -0.78 & 11.10 \\
Agro-services & -1.49 & 3.22 & 6.79 & -3.71 & -4.26 \\
GDP of agribusiness & 1.63 & 0.55 & 6.40 & -1.41 & -6.27 \\
GDP of Paraná & -0.95 & -1.71 & 9.78 & -1.69 & -0.42 \\
\hline
\end{tabular}

Source: Research Data

In the analysis of the participation of agribusiness in the economy of Paraná, it is important to present the contributions of the sector in the collection of indirect taxes. The GDP corresponds to the added value plus the net indirect taxes. The import tax and tax on industrialized products, collected by the Union, and the tax on the circulation of goods and services, collected by the states, corresponding to more than $50 \%$ of indirect taxes. Table 5 shows the distribution of taxes paid in the State of Paraná and the share corresponding to the collection of agribusiness activities. Considering the 2010-2015 period, agribusiness activities collected on average $30.03 \%$ of indirect taxes, reinforcing the importance of this set of economic activities in the regional scenario.

Table 5 - Composition of indirect taxes in the agribusiness of Paraná

\begin{tabular}{ccccccc} 
AGGREGATES & \multicolumn{7}{c}{ Share \% } \\
A - Agro-livestock inputs & 2010 & 2012 & 2012 & 2013 & 2014 & 2015 \\
B - Agro-livestock product & 2.95 & 2.89 & 2.92 & 2.99 & 2.26 & 3,12 \\
C - Agro-industry & 2.44 & 2.19 & 2.24 & 2.62 & 2.01 & 3.89 \\
D - Agro-services & 22.66 & 20.59 & 22.28 & 23.03 & 17.04 & 17.03 \\
Agribusiness taxes (A + B + C + D) & 3.65 & 3.76 & 3.91 & 4.19 & 3.39 & 6.10 \\
E - Industry & 31.71 & 29.42 & 31.35 & 32.84 & 24.70 & 30.15 \\
F - Industrial Services & 41.61 & 44.54 & 42.33 & 42.83 & 34.69 & 31.25 \\
G - Services & 7.75 & 6,92 & 7.27 & 5.04 & 2.40 & 10.33 \\
Taxes from the rest of the economy (E + F + G) & 68.29 & 70.58 & 68.65 & 67.16 & 75.30 & 69.85 \\
INDIRECT TAXES (A + B + C + D + E + F + G) & 100.00 & 100.00 & 100.00 & 100.00 & 100.00 & 100.00 \\
\hline
\end{tabular}

Source: Research Data

It is important to highlight the reduction of $31.25 \%$ in indirect taxes on industrial activity in 2015. More precisely, the economic and political crises in Brazil slowed the production of the automobile industry, affecting the collection of the tax on industrialized products. The expressive advance of industrial services (generation and distribution of electricity and water supply) and services is due to the influence of successive increases in the administered prices of electric energy and fuels, following the federal government control of prices aimed mainly to combat the inflationary process. 


\section{Conclusions}

This article aimed to evaluate the contribution of agribusiness to GDP and the collection of indirect taxes in an important region of Brazil from 2010 to 2015. Thus, the research becomes relevant for presenting in detail the structure of agribusiness in Paraná state and real growth rates by segment (agro-livestock inputs, agro-livestock product, agro-industry, agro-services). In this context, this study brought important contributions to the understanding and composition of agribusiness GDP in an important region in Brazil.

The results show that agribusiness increased participation in the economy from 2010 to 2015, from approximately $28.75 \%$ to $30.74 \%$, respectively. It was observed that the significant increases in soy production and livestock production in the agro-livestock product segment contributed to this expansion in the context of Paraná's economy. Concerning the agro-industrial segment, the result was strongly affected by the economic crisis during the years 2014 and 2015. The poor performance of the food manufacturing industry did not allow agribusiness to increase its participation in the state economy.

Regarding indirect taxes, during the analyzed period, shares decreased by $1.26 \%$ because of the economic downturn in the Brazilian economy. In the current economic crisis that Brazil is facing, increased unemployment, a fiscal crisis in the Union, and rising inflation reflected the slowdown in the economy of Paraná and the reduction of household consumption, directly influencing the volume of taxes collected in the state.

An important factor to emphasize regards the limitation of the research. For studies covering the most recent years, efforts are needed to estimate the output values of the activities that make up agribusiness GDP. This reflects the two-year gap in IBGE's disclosure of regional GDPs. Thus, 2015 refers to a preliminary estimate which must be reviewed when the final data are published by IBGE.

For future studies, we suggest the analysis and evaluation of the economic structure of agribusiness for other Brazilian states. In other units of the Federation, such as Rio Grande do Sul and Mato Grosso do Sul, agribusiness is also one of the main activities of the economic structure. As agribusiness activities are most intensive in water use, input-output analysis can be used to estimate the impact of water use, supporting states in planning the use of these resources.

\section{REFERENCES}

Barros, G. S. A. C., Fachinello, A. L., Silva, A. F., Castro, N. R., \& Mazzucco, B. (2015). A dimensão do agronegócio no estado de São Paulo. Relatório de pesquisa. Retrieved in 2017, May 13, from http://www.cepea.esalq.usp.br/comunicacao/Cepea_RelatarioFinal_PIB\%20SP.pdf

Bonelli, R., Bastos, E. K. X., \& Abreu, P. C. A. (2011). Indicador do PIB do agronegócio do Espírito Santo (Texto para Discussão, No. 20). IJSN. Retrieved in 2017, May 13, from http://www.ijsn.es.gov.br

Brasil. Ministério da Agricultura, Pecuária e Abastecimento - MAPA. (2016). Retrieved in 2016, December 7, from http://www.agricultura.gov.br

Brenes, E. R., Montoya, D., \& Ciravegna, L. (2014). Differentiation strategies in emerging markets: the case of Latin American agribusinesses. Journal of Business Research, 67(5), 847-855.

Castro, F. J. G. (2013). A economia Paranaense em 2013: análise conjuntural (Vol. 35, No. 11-12). Curitiba: IPARDES.

Castro, F. J. G. (2015). A reflexo da conjuntura econômica na economia paranaense em 2014: análise conjuntural (Vol. 35, No. 3-4). Curitiba: IPARDES.

Companhia Nacional de Abastecimento - CONAB. (2014). Acompanhamento da safra brasileira: grãos. Brasília. Retrieved in 2017, December 4, from

http://www.conab.gov.br/OlalaCMS/uploads/arquivos/14_11_13_09_19_35_boletim_graos_novembr o_2014.pdf

Córdoba, D., Selfa, T., Abrams, J. B., \& Sombra, D. (2018). Family farming, agribusiness and the state: Building consent around oil palm expansion in post-neoliberal Brazil. Journal of Rural Studies, 57, 147-156.

Cunha, J. G., Bach, T. M., Silva, W. V., Souza, A., \& Veiga, C. P. (2018). Econometric analysis of cointegration and causality between markets prices toward futures contracts: Evidence from the live cattle market in Brazil. Cogent Business \& Management, 5, 1457861. 
Feijó, C. A., \& Ramos, R. L. O. (2018). Contabilidade social: a nova referência das contas nacionais do Brasil (4. ed.). Rio de Janeiro: Elsevier.

Finamore, E. B., \& Montoya, M. A. (2003). PIB, tributos, emprego, salários e saldo comercial no agronegócio gaúcho. Ensaios FEE, 24(1), 93-126.

Freitas Filho, A., Paez, M. L. D. A., \& Goedert, W. J. (2002). Strategic planning in public R\&D organizations for agribusiness: Brazil and the United States of America. Technological Forecasting and Social Change, 69(8), 833-847. http://dx.doi.org/10.1016/S0040-1625(01)00139-1

Gazeta do Povo. (2016, janeiro 25). Maior exportador de frango em 2015, Paraná quer aumentar embarques. Gazeta do Povo, Curitiba. Retrieved in 2016, May 15, from http://www.gazetadopovo. com.br /agronegocio/maior-exportador-de-frango-em-2015-parana-quer-aumentar-embarques6bqr7slho5hrlxjy1nzqol3hs

Guilhoto, J. J. M., \& Sesso Filho, U. A. (2005). Estimação da matriz de insumo-produto a partir de dados preliminares das contas nacionais. Economia Aplicada, 9(2), 277-299.

Instituto Brasileiro de Geografia e Estatística - IBGE. (2007). Sistema de contas nacionais Brasil (2. ed., Séries Relatórios Metodológicos, No. 24). Rio de Janeiro: IBGE.

Instituto Brasileiro de Geografia e Estatística - IBGE. (2015). Contas regionais do Brasil: 2010-2013: coordenação de contas nacionais. Rio de Janeiro: IBGE.

Ioris, A. A. R. (2016). Rent of agribusiness in the Amazon: a case study from Mato Grosso. Land Use Policy, 59(31), 456-466.

Kureski, K., Moreira, V. R., Veiga, C. P., \& Rodrigues, J. A. (2015). Agribusiness gross domestic product (GDP) in the. Brazilian region of paraná and, the economic development of its agricultural cooperatives. African Journal of Agricultural Research, 10(48), 4384-4394.

Machado Filho, C. P., Caleman, S. M. Q., \& Cunha, D. F. (2017). Governance in agribusiness organizations: challenges in the management of rural family firms. Revista ADM, 52, 81-92. http://dx.doi.org/10.1016/j.rausp.2016.09.004

Martins, G., Mafioletti, R. L., Turra, F. E., Monteiro, A. A., \& Krinski, S. (2014). Agro: conjuntura e cooperativismo. Curitiba: Ocepar/Sescoop/PR.

Moreira, V. R., Kureski, R., \& Veiga, C. P. (2016). Assessment of the economic structure of Brazilian Agribusiness. The Scientific World Journal, 2016, 1-10.

Portal Brasil. (2012). Complexo soja é destaque nas exportações em 2011. Retrieved in 2016, May 14, from http://www.brasil.gov.br/economia-e-emprego/2012/01/complexo-soja-e-destaque-nasexportacoes-em-2011

Portal do Agronegócio. (2014). Retrieved in 2017, September 26, from http://www.portaldoagronegocio.com.br/index.php?p=oquee

Sehnem, S., \& Oliveira, G. P. (2017). Analysis of the supplier and agribusiness relationship. Journal of Cleaner Production, 168, 1335-1347.

Sindicato das Indústrias de Produtos Avícolas do Estado do Paraná - SINDIAVIPAR. (2016). Retrieved in 2017, May 15, from http://www.sindiavipar.com.br/index.php?modulo =8\&acao =frango

U.S. Department of Agriculture - USDA. (2016). World Agro-livestock Production Circular WAP 7-16 July 2016). Washington: FAS/Office of Global Analysis/USDA.

Wilkinson, J., Cerdan, C., \& Dorigon, C. (2017). Geographical indications and 'origin' products in Brazil: the interplay of institutions and networks. World Development, 98, 82-92. http://dx.doi.org/10.1016/j.worlddev.2015.05.003

Submetido: $12 / J u l . / 2018$

Aceito: 23/Dez./2018

Classificação JEL: E01 - Medição e dados sobre Renda nacional e contas de produto e Riqueza 